\title{
Reply to: Comment on 'Tumour antigen expression in hepatocellular carcinoma in a low-endemic western area'
}

\author{
Kostandinos Sideras ${ }^{1}$, Marco J Bruno ${ }^{1}$ and Jaap Kwekkeboom*,1 \\ ${ }^{1}$ Department of Gastroenterology and Hepatology, Erasmus MC-University Medical Centre, NA 1009, 's Gravendijkwal 230, 3015 CE Rotterdam, \\ The Netherlands
}

Sir,

We would like to thank Grizzi et al for their comments to our paper on the expression of tumour antigens in hepatocellular carcinoma (HCC) in a Western European cohort (Sideras et al, 2015). Grizzi et al discuss the international collaborative efforts organised by the 'Society for Immunotherapy of Cancer' with a goal to 'identify hurdles that impede effective translation of cancer immunotherapy' (Fox et al, 2011). One of the hurdles the panel identified was that of cancer complexity. The question arises if studies using tissue microarrays (TMAs) are capable of capturing the complexity of cancer. To answer the question it is important to first consider not only the disadvantages but also the advantages of TMA-based research, and to understand which research question is being asked by the investigators using TMAs.

Tissue microarray technology was developed as an alternative to laborious and costly histological studies utilising full tissue slides (Camp et al, 2008). The advantages are several. Tissue microarrays use small amounts of tissue that markedly increase the number of assays that can be performed per tissue block. In fact, the tissue blocks we used for our study are largely undisturbed after cutting the cores and can be further used to study other questions. Tissue microarrays substantially reduce the amount of antibodies and workload when studying large cohorts of patients. The presence of tissues from multiple patients on a single slide allows for identical experimental conditions.

As pointed out by Grizzi et al, a potential disadvantage of using TMAs is that, in case of tumour heterogeneity, antigens of interest, which are focally expressed, may be missed. However, multiple studies have demonstrated strong correlations between TMAs and whole sections (Camp et al, 2000; Torhorst et al, 2001; O'Grady et al, 2003; Zhang et al, 2003; Bhargava et al, 2004; Schmidt et al, 2009), and it is known that sampling error is reduced inversely to the size of the cohort. Although the correlation also depends on the level of heterogeneity, even heterogeneously expressed antigens have shown reasonable correlations between TMAs and full sections (Camp et al, 2008).

To come back to our study, several cancer testis antigens (CTAs) showed lower prevalence of expression than studies originating in Eastern Asia, where most HCC patients are HBV positive. We provided several explanations to account for these discrepancies. One of them is the discrepancy in aetiology (in our study only $23 \%$ of patients were HBV positive), which has been previously shown to influence the expression of CTAs. For example, in the study by Xia et al, which is quoted by Grizzi et al, the prevalence of MAGE-C1 expression, as examined in full-tumour sections of 46 patients, was 36\% (Xia et al, 2013). However, in HBV-negative patients only $13 \%$ expression was seen, in agreement with our study. We further discussed how our results are in agreement with other similar studies from European cohorts with low HBV prevalence (Riener et al, 2009). On the contrary, the Liang et al study, also quoted, had an HBV prevalence of $88 \%$ (Liang et al, 2013). Incidentally, Liang et al also used TMAs to study CTA expression of the 362 HCC patients in their study. The study by Wang et al, which was not published at the time of submission of our paper, examined tissue from 142 patients using RT-PCR (Wang et al, 2015). However, as we discussed in our paper, mRNA is not always translated to protein, and in fact direct comparisons have shown much lower CTA protein expression than mRNA expression in HCC (Nakamura et al, 2006).

A final point raised by Grizzi et al is regarding the use of the $\mathrm{H}$-score. We agree that this method provides equivalent mathematical products that 'may', biologically, represent different things. We used the $\mathrm{H}$-score only to investigate the possible biologic role of Glypican-3 and SALL-4 co-expression, and we were quite cautious as to the drawn conclusions, indicating that more research is needed to establish such an association. On the other hand, in Figure 2 of our manuscript, we show three-dimentional graphs of the intensities and percentages of expression of several tumour antigens, providing thus a transparent view of our data.

In conclusion, although we agree with Grizzi et al that TMAs are not suitable for answering questions of complex spatial relationships in the tumour microenvironment, or selection of tumour antigens for immunotherapeutic targeting in individual patients, our aim, to compare expression prevalence of a large panel (15) of tumour antigens in HCC, using a relatively large patient cohort (131), justifies the use of TMAs.

\section{CONFLICT OF INTEREST}

The authors declare no conflict of interest.

\section{REFERENCES}

Bhargava R, Lal P, Chen B (2004) Feasibility of using tissue microarrays for the assessment of HER-2 gene amplification by fluorescence in situ hybridization in breast carcinoma. Diagn Mol Pathol 13: 213-216.

Camp RL, Charette LA, Rimm DL (2000) Validation of tissue microarray technology in breast carcinoma. Lab Invest 80: 1943-1949.

Camp RL, Neumeister V, Rimm DL (2008) A decade of tissue microarrays: progress in the discovery and validation of cancer biomarkers. J Clin Oncol 26: 5630-5637.

Fox BA, Schendel DJ, Butterfield LH, Aamdal S, Allison JP, Ascierto PA, Atkins MB, Bartunkova J, Bergmann L, Berinstein N, Bonorino CC, Borden E, Bramson JL, Britten CM, Cao X, Carson WE, Chang AE, Characiejus D, Choudhury AR, Coukos G, de Gruijl T, Dillman RO, Dolstra H, Dranoff G, Durrant LG, Finke JH, Galon J, Gollob JA, Gouttefangeas C, Grizzi F, Guida M, Hakansson L, Hege K, Herberman RB, Hodi FS, Hoos A, Huber C, Hwu P, Imai K, Jaffee EM, Janetzki S, June CH, Kalinski P, Kaufman HL, Kawakami K, Kawakami Y, Keilholtz U, Khleif SN, Kiessling R, Kotlan B, Kroemer G, Lapointe R, Levitsky HI, Lotze MT, Maccalli C, Maio M, Marschner JP, Mastrangelo MJ, Masucci G, Melero I, Melief C, Murphy WJ, Nelson B, Nicolini A, Nishimura MI, Odunsi K, Ohashi PS, O’Donnell-Tormey J, Old LJ, Ottensmeier C, Papamichail M, Parmiani G, Pawelec G, Proietti E, Qin S, Rees R, Ribas A, Ridolfi R, Ritter G, Rivoltini L, Romero PJ, Salem ML, Scheper RJ, Seliger B, Sharma P, Shiku H, Singh-Jasuja H, Song W, Straten PT, Tahara H, Tian Z, van Der Burg SH, von Hoegen $\mathrm{P}$, Wang E, Welters MJ, Winter H, Withington T, Wolchok JD, Xiao W, Zitvogel L, Zwierzina H, Marincola FM, Gajewski TF, Wigginton JM, Disis ML (2011) Defining the critical hurdles in cancer immunotherapy. J Transl Med 9: 214.

Liang J, Ding T, Guo ZW, Yu XJ, Hu YZ, Zheng L, Xu J (2013) Expression pattern of tumour-associated antigens in hepatocellular carcinoma: association with immune infiltration and disease progression. Br J Cancer 109: 1031-1039.

Nakamura S, Nouso K, Noguchi Y, Higashi T, Ono T, Jungbluth A, Chen YT, Old LJ, Nakayama E, Shiratori Y (2006) Expression and immunogenicity of NYESO-1 in hepatocellular carcinoma. J Gastroenterol Hepatol 21: 1281-1285.

O'Grady A, Flahavan CM, Kay EW, Barrett HL, Leader MB (2003) HER-2 analysis in tissue microarrays of archival human breast cancer: comparison of immunohistochemistry and fluorescence in situ hybridization. Appl Immunohistochem Mol Morphol 11: 177-182.

Riener MO, Wild PJ, Soll C, Knuth A, Jin B, Jungbluth A, Hellerbrand C, Clavien PA, Moch H, Jochum W (2009) Frequent expression of the novel cancer testis antigen MAGE-C2/CT-10 in hepatocellular carcinoma. Int J Cancer 124: 352-357.

Schmidt LH, Biesterfeld S, Kummel A, Faldum A, Sebastian M, Taube C, Buhll R, Wiewrodt R (2009) Tissue microarrays are reliable tools for the clinicopathological characterization of lung cancer tissue. Anticancer Res 29: 201-209.

Sideras K, Bots SJ, Biermann K, Sprengers D, Polak WG, IJzermans JN, de Man RA, Pan Q, Sleijfer S, Bruno MJ, Kwekkeboom J (2015) Tumour antigen expression in hepatocellular carcinoma in a low-endemic western area. Br I Cancer 112: 1911-1920.

Torhorst J, Bucher C, Kononen J, Haas P, Zuber M, Kochli OR, Mross F, Dieterich H, Moch H, Mihatsch M, Kallioniemi OP, Sauter G (2001) Tissue microarrays for rapid linking of molecular changes to clinical endpoints. Am J Pathol 159: 2249-2256.

Wang M, Li J, Wang L, Chen X, Zhang Z, Yue D, Ping Y, Shi X, Huang L, Zhang T, Yang L, Zhao Y, Ma X, Li D, Fan Z, Zhao L, Tang Z, Zhai W, Zhang B, 
Zhang Y (2015) Combined cancer testis antigens enhanced prediction accuracy for prognosis of patients with hepatocellular carcinoma. Int J Clin Exp Pathol 8: 3513-3528.

Xia QY, Liu S, Li FQ, Huang WB, Shi LN, Zhou XJ (2013) Sperm protein 17, MAGE-C1 and NY-ESO-1 in hepatocellular carcinoma: expression frequency and their correlation with clinical parameters. Int J Clin Exp Pathol 6: 1610-1616.

Zhang D, Salto-Tellez M, Putti TC, Do E, Koay ES (2003) Reliability of tissue microarrays in detecting protein expression and gene amplification in breast cancer. Mod Pathol 16: 79-84.

*Correspondence: Dr J Kwekkeboom; E-mail: j.kwekkeboom@erasmusmc.nl Published online 14 April 2016

(c) 2016 Cancer Research UK. All rights reserved 0007-0920/16 